\title{
The Conflict Between Managers and Shareholders in Diversifying Acquisitions: A Portfolio Theory Approach
}

Twenty-five billion dollars were expended in connection with mergers and acquisitions in the first nine months of $1978 . .^{1}$ One of the most frequently asserted justifications for these transactions is the acquiring company's desire to diversify into another industry or product line. ${ }^{2}$ Diversification by a corporation, however, may produce conflicts $^{3}$ between management's personal interests and the goal of maximizing shareholder wealth. ${ }^{4}$ This Note applies portfolio theory to managerial behavior in order to demonstrate that decisions to diversify are influenced by factors other than the maximization of shareholder wealth. Although empirical evidence suggests that acquisitions may represent a net transfer of wealth from the shareholders of the acquirer to the shareholders of the target, ${ }^{5}$ existing law focuses on protection of the target's shareholders. ${ }^{6}$ Since neither current legal remedies nor the sale of one's shares in the marketplace provide adequate protection for the shareholders of the acquiring company, ${ }^{7}$ this Note argues that the business judgment rule should be suspended in order to permit thorough judicial scrutiny of the fairness of acquisition decisions.

\section{The Nature of the Conflict}

The conflict between managers and shareholders arises from two sources, namely, the additional risks ${ }^{8}$ that managers incur because of

1. Wall St. J., Oct. 18,1978 , at 33 , col. 2.

2. See Salter \& Weinhold, Diversification via acquisition: creating value, HARv. Bus. REv., July-Aug. 1978, at 166. For examples of executives' statements offering diversification as the primary justification for merger, see Wall St. J., Nov. 29, 1978, at 5, col. 1 (proposed Firestone Tire \& Rubber Co. merger with Borg.Warner Corp.); id., Nov. 22, 1978, at 3, col. 2 (proposed Avon Products, Inc. merger with Tiffany \& Co.).

3. See generally S. ReID, Mergers, MANagers, and the Economy 133-49 (1968); Donaldson, Financial Goals: Management vs. Stockholders, HAkv. Bus. REv., May-June 1963, at 116.

4. Maximization of shareholder wealth has long been accepted in economic theory as the proper goal of management in conducting the affairs of a publicly owned corporation. J. Van Horne, Financial Management and Policy 6-9 (4th ed. 1977); cf. Hetherington, Fact and Legal Theory: Shareholders, Managers, and Corporate Social Responsibility, 21 Sran. L. REv. 248, 250-74 (1969) (current legal theory requiring managers to run corporation for benefit of shareholders should be abandoned).

5. Gort \& Hogarty, New Evidence on Mergers, 13 J.L. \& EcoN. 167, 183 (1970).

6. See pp. 1248-51 infra.

7. See, e.g., M. Eisenberg, The Structure of the Corporation 79-84 (1976).

8. See Donaldson, supra note 3 , at 121 (shareholders' risk standard formed from perspective of diversified investor; managers' risk standard based on preserving individual corporate entity and managers' goals). 


\section{Diversifying Acquisitions}

executive compensation plans and the psychological benefits that managers gain as a result of their corporate positions. ${ }^{9}$ Diversification affords an opportunity to improve managerial positions with respect to both of these factors. By the use of portfolio theory, ${ }^{10}$ on the other hand, it can be demonstrated that shareholders of acquiring companies incur actual damages in the absence of benefits other than diversification.

\section{A. Portfolio Theory and Shareholders' Risks}

Investment securities are analyzed in terms of two characteristics: return and risk. ${ }^{11}$ The return to the investor from a stock is defined as the cash dividends received plus any appreciation in market price during the holding period.12 The total risk associated with the return from a security is due to the possibility that the actual return at the end of the holding period will differ from the return expected at the beginning of that period. ${ }^{13}$ This risk consists of two components: market risk, or changes in returns due to general market fluctuation, and firm-specific risk, or changes in returns due to factors peculiar to the individual company. ${ }^{14}$ As most investors are risk-averse, ${ }^{15}$ they will not accept additional risks without receiving increased returns. Since risk and return are interdependent, the riskiness of a given security will determine the return that investors expect to receive before they will purchase that security.

Portfolio theory enables the investor to analyze the risks and returns that he can expect to receive from a group, or portfolio, of securities

9. See R. Gordon, Business Leadership in the Large Corporation 305-12 (1945) (most important nonfinancial incentive offered by large corporation is opportunity to satisfy desire for personal power and prestige).

10. Portfolio theory is a commonly accepted method of financial analysis. See J. VAN Horne, supra note 4, at 5-6; J. Weston \& E. Brigham, Managerial Finance 364-77 (5th ed. 1975). See generally H. Markowitz, Portfolio Selection (1959); W. Sharpe, Portfolio Theory and Capital Markets (1970). For nontechnical explanations, see B. MalKiel, A Random Walk Down Wall Street $182-86$ (rev. ed. 1975); Bines, Modern Portfolio Theory and Investment Management Law: Refinement of Legal Doctrine, 76 Colum. L. REV. 721, 734-50 (1976).

11. J. VAN HORNE, supra note 4, at 15 .

12. Id. at 20.

13. Id. at 15. The larger the number of possible returns, the higher the risk of the security. See Pogue \& Lall, Corporate Finance: An Overview, in MOdern Developments IN Financial Management 29 (S. Myers ed. 1976).

14. In financial theory, market risk is called systematic risk and firm-specific risk is called unsystematic risk. See J. VAN HORNE, supra note 4, at 61; J. WeSTON \& E. BRighaM, supra note 10 , at 659 . For a thorough explanation aimed at the nonexpert investor, see $B$. MaLkIEL, supra note 10 , at 187-94.

15. For most investors, satisfaction increases at a decreasing rate with successive additions to wealth. By definition, these investors are risk-averse. See J. WEston \& E. BrighaM, supra note 10, at 318-19. 
rather than from a single security. ${ }^{16}$ The expected return ${ }^{17}$ from a portfolio is measured by the weighted average ${ }^{18}$ of the expected return from each security contained in the portfolio. The risk of a portfolio, however, is not measured by the weighted average of the risk of each security, but is a function of the degree of correlation between the fluctuations in returns from the securities in the portfolio. ${ }^{10}$ For example, poor returns from umbrella companies due to abnormally sunny weather will be offset by better than normal returns from suntan lotion companies. This characteristic of a portfolio makes possible a reduction in risk without a reduction in the level of returns. As long as the individual stocks in a portfolio do not possess identical risk-return characteristics, the risk of such a diversified portfolio as a whole will be less than the weighted average of the individual stocks of which it is comprised. ${ }^{20}$ The return from the portfolio, however, will continue to be the weighted average of the individual returns. ${ }^{21}$

Once adequate diversification has been achieved, ${ }^{22}$ any return that

16. B. MALKIEL, supra note 10, at 182-86; see J. VAN HORNE, supra note 4, at 50.

17. The expected return from a portfolio or a security is defined as the mean of the probability distribution of all possible returns from that portfolio or security. See, e.g., Bines, supra note 10 , at $735-38$.

18. A weighted average is calculated by summing the products of the expected return from each security and the proportion of funds invested in each security. See, e.g., J. VAN HORNe, supra note 4, at 48.

19. Id. at 48-49. Securities with identical risk-return characteristics are perfectly positively correlated, that is, the returns from each stock fluctuate in the same direction at all times. Securities that move in opposite directions at all times are perfectly negatively correlated. Most stocks are less than perfectly positively correlated, that is, they respond "neither entirely in phase nor entirely out of phase to events." Bines, supra note 10, at 746.

20. Pogue \& Lall, supra note 13 , at 30 .

21. The risk-reduction benefits can be demonstrated by the following example: Assume that one stock, an umbrella company, yields $20 \%$ in rainy weather and $0 \%$ in sunny weather, while another, a suntan lotion company, yields $20 \%$ in sunny weather and $0 \%$ in rainy weather. If it is sunny $50 \%$ of the time and rainy $50 \%$ of the time, then the expected annual return for each company is $10 \%$. If an investor has a total of $\$ 100$ to invest and places it all in the umbrella company, he can expect to receive, on average, $\$ 10$ per year. However, he faces the risk that in any given year the $50 \%$ probability of rainy weather will not materialize. If one year it is sunny $75 \%$ of the time, the investor will receive only $\$ 5$. Now, suppose there is a second investor with $\$ 100$ who invests $\$ 50$ in the umbrella company and $\$ 50$ in the suntan lotion company. His expected return is $\$ 5$ from each company for a total of $\$ 10$. His risk, howerer, has been completely eliminated; he will receive $\$ 10$ regardless of what the weather pattern is in any given year. If it is sunny $75 \%$ of the year, he will receive only $\$ 2.50$ from the umbrella company. However, he will receive $\$ 7.50$ from the suntan lotion company and, therefore, carn his expected $10 \%$. Clearly, this second investor has found a better deal. See B. MalkieL, supra note 10 , at $183-85$.

22. If it were possible to find two perfectly negatively correlated stocks, see note 19 supra, an investor would need to purchase only those two stocks in order to eliminate all firm-specific fluctuations and achieve complete diversification. See B. MalkIeL, supra note 10 , at 185. Although two such stocks are virtually impossible to find, see id., the 


\section{Diversifying Acquisitions}

represents compensation for firm-specific ${ }^{23}$ risk will be quickly bid away by rational investors ${ }^{24}$ who recognize the possibility of gain that exists in eliminating the risk and maintaining the return by placing the security within a portfolio. ${ }^{25}$ However, the investor who has eliminated firm-specific risk must still take market risk into account in evaluating a security; ${ }^{26}$ some stocks are more volatile than others in relation to the market index. ${ }^{27}$ Since market risk cannot be eliminated, the riskaverse investor will require greater returns for stocks with higher volatility. ${ }^{28}$ Thus, the return required from a security will be a function of that security's market risk..$^{29}$

Since the rational investor always owns a diversified portfolio, the wealth of that investor is maximized only if returns from a company in which he owns stock are increased or market risk is decreased. The reduction of firm-specific risk at the corporate level does not create added value for him; the price of his shares already reflects all gains obtainable through diversification.

\section{B. Portfolio Theory and Managers' Risks}

The principles of portfolio theory can also be employed to predict managerial behavior under conditions of uncertainty. ${ }^{30}$ Most executives of publicly owned corporations are compensated for their work by a base salary plus a bonus of cash, stock options, deferred compensa-

combination of 10 to 20 less than perfectly positively correlated stocks is adequate to obtain sufficiently complete diversification, id. at 190; Markowitz, Markowitz Revisited, Financial ANalysts J., Sept.-Oct. 1976, at 50.

23. See note 14 supra.

24. A rational investor is one who always seeks to maximize his expected returns for the level of risk he is willing to assume. Although there may be nonrational investors in the market, their responses and actions will be random and, hence, will not affect the result arising from simultaneous actions by rational investors.

25. See B. Malkiel, supra note 10, at 190 n.**; J. Weston \& E. Brigham, supra note 10 , at 377.

26. See J. VAN HoRne, supra note 4, at 62-63. Even a well-diversified portfolio remains exposed to market fluctuations. J. Weston \& E. BRigham, supra note 10, at 659.

27. See J. VAN HoRNe, supra note 4, at 59.60; J. Weston \&. E. BRIGHAM, supra note 10, at 662 .

28. J. VAN HORNE, supra note 4, at 64-65. Risk-averse investors require additional returns for bearing added risks, but, as only market risk is relevant to well-diversified investors, they will require extra rewards solely for increases in such risks. Therefore, a graphic representation of the relationship between the return from a security and its market risk will be linear. Id. at 63 .

29. Id. at 63-64.

30. Typically, portfolio theory has been applied to the risks incurred by sharcholders rather than by managers. See, e.g., W. SHARPE, supra note 10, at 96-103 (portfolio theory used to delineate two kinds of risks associated with holding securities; firm-specific risk and market risk); Bines, supra note 10 , at $750-97$ (portfolio theory used to explore investment-fund manager's fiduciary duties to investors in selecting and adjusting fund's portfolio). 
tion, or increased retirement benefits. ${ }^{31}$ The amount of the bonus is generally based on the financial performance of the company during the preceding fiscal year ${ }^{32}$ and it is intended to create incentives for management to maximize corporate performance. ${ }^{33}$ Since corporate performance fluctuates with firm-specific variables, managers are subjected to the same firm-specific risk, with respect to their corporate compensation, ${ }^{34}$ as is a hypothetical investor who holds the stock of only that one company.

A predictable response by the risk-averse manager is diversification of his investments in order to minimize the firm-specific risks associated with his compensation. ${ }^{35}$ However, managers are unlikely to command the amount of personal wealth necessary to obtain the minimal level of diversification. ${ }^{36}$ Thus, unlike rational shareholders, they remain ex-

31. See D. Mclaughlin, The Executive Money Map 122 \& n.2 (1975) (detailed analysis of proxy statements of 550 leading companies found that $76 \%$ of these companies had bonus plans in 1973).

32. Id. at 128-37 (total amount available for payment of bonuses to all eligible executives is calculated, in $85 \%$ of companies surveyed, by fixed formula based on percentage of profits).

33. Id. at 122. Empirical studies have concluded that executive compensation is more closely tied to corporate sales than corporate profits. The distribution of the total pool of funds among eligible executives can be based on a fixed or graduated percentage of salary, on divisional performance, or on individual achievement. Id. at 127-30. However, "[t]he final decisions in 95 companies out of 100 will be made on a judgmental basis, regardless of the formal administrative system." Id. at 132. Therefore, the basis used by top management in evaluating individual performance and setting bonuses is apparently the level of and growth in sales. This is entirely consistent with the psychological factors that lead managers to emphasize size and growth. See p. 1243 infra. For a survey of the empirical studies, see S. REID, supra note 3, at 135-36. But see Lewellen \& Funtsman, Managerial Pay and Corporate Performance, 60 AM. Econ. REv. 710 (1970) (exccutive compensation more strongly influenced by profit and stock performance than sales). Bonuses range from $10 \%$ of a lower-echelon manager's salary up to $50 \%$ of the salary of top executives. D. McLavghlin, supra note 31, at 129.

34. See, e.g., D. Mclaughlin, supra note 31, at 130 (executive's compensation dropped by $\$ 400,000$ when company failed to pay bonuses; average partner compensation in securities firm dropped from $\$ 124,000$ to $\$ 25,000$ in one year due to economic difficulties).

35. See J. Mossin, Security Pricing Theory and Its Implications for Corporate INvESTMENT DECisions 10 (1972) ("The investor may have various types of nonportfolio income that are correlated with certain securities. An architect's professional income may be closely correlated with earnings in the construction and building-materials industries. A rational portfolio would in this case include relatively fewer shares in these industries.")

36. In order to obtain the minimal level of adequate diversification, the manager would need to invest his money in at least nine other companies, all of which have returns that are less than perfectly positively correlated with the variations in his compensation. Although the amount of funds invested in each security to achieve adequate diversification depends on a variety of factors, it is likely that the income streams from each investment would need to be roughly equivalent to the amount of the bonus. At prevailing interest rates, a manager receiving a bonus as modest as $\$ 50,000$ would need several million dollars of investment capital to eliminate the firm-specific risk resulting from his compensation. Formulas for calculation of the exact amount of capital required are not available from secondary sources but can be derived from the basic principles of portfolio selection. See Bines, supra note 10, at $743-49$. 


\section{Diversifying Acquisitions}

posed to the fluctuations in returns arising from the firm-specific risks of their company. ${ }^{37}$

Managerial behavior is also influenced by factors other than firmspecific risk. Managers gain psychological rewards from their positions of authority within the corporation. ${ }^{38}$ Leadership of a successful company brings a manager power and prestige, ${ }^{39}$ the possibility of losing these benefits is regarded by managers as a traumatic experience. ${ }^{40}$ Even a manager wealthy enough to eliminate the risk of his incentive pay by diversification cannot reduce the possibility of loss of these significant psychological benefits.

The only effective method of lessening the risks of unstable earnings to managers is to diversify at the corporate level. ${ }^{41}$ Diversification can be achieved either by internal expansion into other product markets or by the acquisition of companies involved in businesses unrelated to that of the acquiring corporation. ${ }^{42}$ In either case, managers are, in essence, creating a portfolio of investments for the corporation as a whole. This enables them to decrease the corporation's firm-specific risk, and the concomitant risk associated with their own compensation. Moreover, psychological benefits increase with an increase in size, because size adds to the longevity of the firm and reduces the possibility of a takeover. Thus size adds to the job security of management. ${ }^{43}$ Moreover, managerial power and prestige increase with

37. If corporate profitability is improved through incentive plans, as some commentators assert, see D. McLaughlin, supra note 31, at 122; Masson, Executive Motivations, Earnings and Consequent Equity Performance, 79 J. Political Econ. 1278, 1285.90 (1971), then it is to shareholders' advantage that managers not diversify away the risk built into their compensation plans through a personal portfolio. However, these risks may lead managers to take other actions that are not in the best interests of shareholders. See pp. 1243-44 infra; M. Eisenberg, supra note 7, at 30-31; J. Galbraith, The New INDustrial State 136-66 (3d ed. 1978).

38. R. Gordon, supra note 9 , at 305-07.

39. M. EISENBERG, supra note 7, at 3I; R. Gordon, supra note 9, at 305-07.

40. James $E$. Ling, the chief executive officer of the conglomerate, Ling-Temco-Vought, Inc., stated the reasons for his company's diversification program:

As late as 1964, 90\% of LTV's business was committed to the military and space agencies. The management of LTV had suffered a number of traumatic experiences as the result of cutbacks in aircraft and missile programs. Thus, we were determined that never again would we be dependent upon any one product, market or technology to sustain our growth and progress.

E. Kintner, Primer on the Law of Mergers 20 (1973) (emphasis added).

41. See M. EIsenberg, supra note 7, at 31; Donaldson, supra note 3, at 127; Mueller, $A$ Theory of Conglomerate Mergers, 83 Q.J. EcoN. 643, 657 (1969).

42. For reasons why internal diversification does not create the same dangers as diversification by acquisition, see note 76 infra.

43. Increased size means the controlling share of a company is more expensive and thus may discourage potential acquirers. Decreased liquidity also reduces surplus funds available to the acquirer once the transaction is completed. Both increasing size and reducing liquidity are utilized as defensive strategies by potential target companies to defeat a takeover. See A. Fleischer, Tender Offers: Defenses, Responses, and Planning 36 (1978). 
the size of the corporation. ${ }^{44}$ These psychological, as well as financial, incentives cause management to favor corporate acquisition programs, regardless of the effect of that policy on profitability. ${ }^{45}$

\section{The Sources of Damage to Shareholders}

Since investment decisions afford managers the opportunity for reducing the firm-specific risk to which they are subjected by executive compensation plans as well as for satisfying personal motivations, ${ }^{40}$ and since the fastest method of achieving these goals is acquisition of another company, ${ }^{47}$ acquisitions present the greatest source of possible conflict with shareholder interests. ${ }^{48}$

\section{A. The Costs of Acquisitions}

Since rational shareholders have already eliminated firm-specific risk through portfolio diversification, they gain nothing from the reduction of that risk by a corporate acquisition. ${ }^{49}$ In order to benefit shareholders, an acquisition must result in synergy. ${ }^{50}$ Synergy occurs when the value of the companies combined is greater than the sum of the

44. See R. Gordon, supra note 9, at 307 ("As in the case of personal power, prestige is to some extent linked with the size of the firm, and too strong a desire for it may lead to overexpansion."); Mueller, supra note 41 , at 644 ("[T] agers derive from their occupations are directly related to the size and growth of the company and not to its profitability.")

45. See S. ReID, supra note 3, at 134-39; Mueller, supra note 41, at 656-57.

46. See M. Eisenberg, supra note 7 , at $30-34$; cf. Stapleton, Portfolio Analysis, Stock Valuation and Capital Budgeting Decision Rules for Risky Projects, 26 J. Finance 95, 11117 (1971) (managers should consider only market risk in evaluating investment projects).

47. See J. Galbraith, Economics and the Public Purpose 105-07 (1973); Mueller, stupra note 41 , at $647-48,657$. Managers could also decrease their own firm-specific risks by investing corporate funds in the securities of other corporations. This would not only provide risk reduction but would also permit managers to diversify without paying an acquisition premium. But such a strategy, although attractive for risk-reduction purposes, is not often observed in practice. Heavy investment in publicly traded securities would be a clear indication that management has run out of high-yielding investment ideas for corporate funds and is thus performing less than optimally. In addition, managers are, presumably, better suited for running a business than managing an investment fund. Finally, a large fund of liquid investments in other securities is a tempting asset to a potential hostile acquirer.

48. S. REID, supra note 3, at 148; see E. KINTNER, supra note 40 , at 24 (large merging firms have exhibited tendency to achieve growth by merger even at cost to shareholders). Diversification through internal expansion may also conflict with sharcholder goals if it provides no benefits above its cost. However, certain protections for sharcholders are built into the internal diversification process. See note 76 infra.

49. See J. Mossin, supra note 35 , at 9 (there is no need for individual company to diversify as stockholders can do so on their own); Stapleton, supra note 46, at 111 "'The company cannot benefit its shareholders by diversifying investments within the company."); cf. Salter \& Weinhold, supra note 2, at 168-69 (systematic risk of conglomerate differs insignificantly from that of comparable portfolio).

50. See J. VAN HoRNE, supra note 4, at 220-22, 632; Mueller, supra note 41, at 652-53. 
values of each company separately. ${ }^{51}$ This result is possible only if operational or financial economies are produced by the combination. ${ }^{52}$ Operational economies are the most common source of synergy, but are usually available only in combinations of related businesses that result in horizontal or vertical integration. ${ }^{53}$ Conglomerate acquisitions, in which two unrelated businesses are combined, rarely produce operating economies; ${ }^{54}$ their only potential source of synergy is financial economies, such as centralized cash balances, transfer of working-capital funds among divisions, and reinvestment of excess funds internally. ${ }^{55}$

51. J. VAN HORNE, supra note 4 , at 630 .

52. Id. at 630 . The term "synergy," as defined here, does not include the misapplication of the word to illusory gains in earnings per share. In the 1960s, synergy was used to describe the gain that occurred when a company with a high price-carnings ratio (P/E) purchased a company with a low P/E. The "synergy" occurred because the carnings of the acquired company were supposedly evaluated by the market at the acquirer's $P / E$ after the acquisition, producing a market value for the combined companies in excess of the sum of their separate values. For a thorough explanation of the mechanics of this process, see B. MaLkiel, supra note 10, at 56-60. This manufactured growth only works, however, as long as acquisitions grow exponentially in each successive year, and as long as the market does not discount the growth as illusory. For several years in the mid1960 s, the market did not discount the growth and the value of actively merging firms soared, perhaps under the "greater fool" theory. Id. at 60; see id. at 24 (no matter what price one pays for stock, there is always someone else who will pay higher price).

By the late 1960s, conglomerates could no longer find the necessary volume of acquisitions, nor could they always competently manage the disparate businesses they had already accumulated. By 1969, the market in conglomerate stock had plunged drastically. See id. at 63 . Today there is no longer any reason to believe that the market, even under the greater fool theory, will find value in this false synergy. See Myers, A Framework for Evaluating Mergers, in Modern Developments in Financial Management 640 (S. Myers ed. 1976). The $P / E$ ratio of the combined company will most likely be the weighted average of the P/E's of each company prior to acquisition. J. VAN HoRNE, supra note 4, at 639 .

53. Operational economies arise if duplicate facilities, such as manufacturing, distributional, or marketing networks, can be eliminated by means of a horizontal combination, or if more control over the supply of raw materials or distribution of the end product can be obtained by means of a vertical combination. For a detailed analysis of each category of operating economy and the possibility of its realization, see Alberts, The Profitability of Growth by Merger, in THE Corporate Merger 247-62 (W. Alberts \& J. Segall eds. 1966); Myers, supra note 52 , at $635-37$.

54. J. VAN HoRne, supra note 4, at 630; Mueller, supra note 41, at 650-51.

55. See Levy \& Sarnat, Diversification, Portfolio Analysis and the Uneasy Case for Conglomerate Mergers, 25 J. Finance 795, 801 (1970); Mueller, supra note 41, at 651-53; Salter \& Weinhold, supra note 2, at 171-76. It has also been argued that the more stable cash-flow stream produced by a diversifying or conglomerate merger creates added debt capacity beyond the sum available to each company separately. See, e.g., Lewellen, $A$ Pure Financial Rationale for the Conglomerate Merger, 26 J. Finance 521, 525-28 (1971). That argument is founded on the concept that the debt capacity of a firm is a function of the level and volatility of cash-flow streams. The level of the combined firm's cash flow is simply the sum of each company's separate flows, but volatility, like the standard deviation of a portfolio, has a covariance effect and is, therefore, less than the sum of the volatility of each separate stream. See J. VAN Horne, supra note 4, at 221. This argument has been disputed by theorists who have pointed out that merger has the conscquence of removing the separate, limited liabilities of each firm. See Bierman \& Thomas, A Note on Mergers and Risk, 19 Antrrkust BulL. 523 (1974); Rubinstein, A Mean-Variance Synthesis of Corporate Financial Theory', in Modern DeVEropments in Financial MaNAGEMENT, supra note 52 , at 54 . 
Although it is often asserted that shareholders should be indifferent toward a nonsynergistic merger, since the transaction is merely additive, ${ }^{56}$ there is both theoretical and empirical support for the contrary position. In order to induce either controlling shareholders or a majority of the shareholders of widely held shares of a target company to sell, a premium over the current market price must be offered. ${ }^{57}$ In recent years, the size of premiums paid has risen dramatically. ${ }^{58}$ In 1977 , the premium paid over the market value of the shares of the acquired firm four weeks prior to announcement of the acquisition averaged seventy-five percent for friendly offers and ninety-one percent for offers made after competing bids..$^{59}$ Of course, once such a premium is paid, the acquirer's shareholders cannot gain from the acquisition in the absence of synergistic benefits in excess of that premium. ${ }^{00}$

The weight of empirical evidence supports a finding that the longrun investment performance of actively acquiring companies is not superior to that of nonacquiring companies: ${ }^{61}$ acquisitions are not justified by improved performance of the acquirer sufficient to outweigh the costs of these transactions. In fact, randomly selected diversified portfolios outperform conglomerates in terms of both rate of return on assets and accumulation of shareholder wealth. ${ }^{62}$ Moreover, the investment performance of the stock of active, industrial acquirers is generally worse than the average investment performance of companies in the industry in which the acquirer was originally categorized. ${ }^{63}$ Thus, acquisitions are risky investments; some produce very high longrun returns, but most do not. ${ }^{64}$ Empirical evidence also suggests that the shortrun performance of an acquirer's stock is not

56. See U. Reinhardt, Mergers and Consolidations: A Corporate Finance Approach 47 (1972); Levy \& Sarnat, supra note 55, at 796-99.

57. J. VAN HORNE, supra note 4 , at $219,638$.

58. The lower premiums paid until recently may explain why the damage to acquirers' shareholders has not been widely recognized. There is a greater possibility that synergistic benefits will be sufficient to offset a $25 \%$ premium than a $90 \%$ premium.

59. Chatlos, The SEC vs. Investors on Tender Offers, Harv. Bus. REv., Sept.-Oct. 1978, at 7.

60. J. VAN HoRNe, supra note 4, at 219-20.

61. See pp. 1246-47 infra.

62. Mason \& Goudzwaard, Performance of Conglomerate Firms: A Portfolio Approach,

31 J. Finance 39, 39, 45 (1976).

63. See Hogarty, The Profitability of Corporate Mergers, 43 J. Bus. 317, 325 (1970). Investment performance is defined as returns to shareholders from dividends and appreciation in market value. $I d$. at 317 n.7. If synergistic benefits arise from the acquisition, the gain to the corporation will be reflected in the price of the acquirer's shares. Id. at 318; see R. Brealey, Security Prices in a Competitive Market 55-56 (1971) (shareholders fare better when growth arises from internal investment rather than by acquisition of another company); S. REID, supra note 3, at 193-94, 228-31 (banks and other companies that grew internally had significantly better profits than those that grew by merger).

64. Gort \& Hogarty, supra note 5, at 176; Hogarty, supra note 63 , at 326 . 
adequate to offset the premium. ${ }^{65}$ The value of acquirers' shares drops an average of two percent at the announcement of an impending acquisition. ${ }^{68}$

The key variable that explains losses to the acquirers' shareholders is the premium over market price paid to the shareholders of the target company. ${ }^{67}$ The price of the acquirer's stock varies inversely with the size of the premium..$^{88}$ In fact, it appears that acquiring firms are penalized by an amount greater than the actual premium paid, because investors assume that the firm will overpay in subsequent transactions. ${ }^{60}$ Thus, the evidence indicates that "mergers tend to result in a net transfer of wealth from the owners of buying firms to the owners of the sellers."70

\section{B. The Failure of the Market for Corporate Control}

The opportunity to sell shares in the marketplace is inadequate protection for the shareholder dissatisfied with management actions. ${ }^{71}$ The market-for-corporate-control theory claims that the market serves as protection in two ways: (1) as a medium for exchange, since a shareholder can liquidate his investment at will; and (2) as a deterrent to management, since poor management decisionmaking will result in decreased share prices and thus increase the possibility of takeover by another company. ${ }^{72}$

Both elements of this theory, however, are refuted by recent data. First, the changed expectations of investors due to an announcement of an acquisition is immediately compounded into the price of a security by the actions of shareholders on the margin. ${ }^{73}$ Only those

65. See, e.g., Wall St. J., Oct. 11, 1978, at 47, col. 3 (upon announcement of acquisition with limited possibilities of synergy, acquirer's stock dropped $7 \%$ ).

66. R. BREALEY, supra note 63 , at 54-55. The same study found that the value of the target's shares rose $13 \%$ in the month the announcement was made. $I d$.

67. Gort \& Hogarty, supra note 5, at 177.

68. Kohers \& Conn, The Effect of Merger Announcement on Share Prices of Acquiring Firms, Rev. Bus. \& ECON. RESEARCH, Fall 1976, at 60-61. The authors found only four of 16 variables considered had a significant impact on share value, and that the stock price varied inversely with three of them: amount of the premium, change in total assets, and change in stability of earnings. Id. at 60; cf. Salter \& Weinhold, supra note 2, at 169 (" $[\mathrm{T}]$ he market may be more interested in growth and the productivity of invested capital than in earnings stability per se.")

69. Gort \& Hogarty, supra note 5, at 180.

70. Id. at 183 .

71. For examples of this "market-for-corporate-control" argument, see Hetherington, supra note 4, at 263-72; Manne, Mergers and the Market for Corporate Control, $73 \mathrm{~J}$. Political Econ. 110 (1965).

72. Hetherington, supra note 4, at 263-72; Manne, supra note 71, at 112-13.

73. Fama, The Behavior of Stock-Market Prices, 38 J. Bus. 34, $38-39$ (1965); see Note, The Measure of Damages in Rule 10b-5 Cases Involving Actively Traded Securities, 26 STAN. L. REv. 37I, 387 n.83 (1974) (price figure for day or week accurately mirrors impact 
shareholders who have access to a constant and immediate flow of information can be sure of acting before the price has dropped. Second, most targets of acquisitions are well-managed, profitable companies. ${ }^{74}$ In addition, it is difficult to see how the market will deter management when any acquisition, regardless of its wisdom, discourages a potential takeover by increasing the size of the company and decreasing its liquidity. ${ }^{75}$

\section{The Inadequacy of Current Law and a Proposal for Reform}

\section{A. Current Law}

Because the marketplace provides inadequate protection for the shareholder of an acquirer engaged in a nonsynergistic acquisition, ${ }^{70}$ the law should provide a source of protection. At common law, there are few judicial remedies available to the shareholder of an acquirer who believes he has been damaged by a nonsynergistic acquisition.77 Acquisitions are rarely ultra vires; ${ }^{78}$ they are legal unless they are

of information during that period). Shareholders on the margin are active investors who immediately react, by buying or selling shares, to any new information about the company. Their actions ensure that the current market price of a stock reflects its intrinsic value based on all available information. See B. MAI.KIEL, supra note 10, at 170-73.

74. See Wall St. J., Sept. 6, 1978, at 1, col. 6. See generally Dean \& Smith, The Relationships Between Profitability and Size, in The Corporate Merger 12-13 (W. Albert \& J. Segall eds. 1966).

75. See note 43 supra.

76. Although internal expansion may present similar dangers, there is reason to believe that these dangers will be less likely to materialize. Managers are likely to diversify into a product line that they are familiar with and that is in some way compatible with the company's existing business. Therefore, the possibilities of synergy, arising from the use of either existing management knowledge or existing manufacturing, distributing, or sales networks, are greater. In addition, no acquisition premium must be paid for internal diversification. See Myers, supra note 52, at 635.

Furthermore, the process of internal expansion is gradual; the impact of the announcement of internal diversification on the price of the shares is discounted and immediate price changes are minimal. Cf. S. ReID, supra note 3, at 164 (in study of 478 large American industrial firms from 1951 to 1961 , those that expanded solely by internal growth better served shareholder interests than those that grew by merger).

77. The lack of legal remedies for acquirers' shareholders arises from the belief that little damage, other than dilution of ownership, will be incurred because shareholders are free to sell their shares. This assumption is reflected in those state statutes that deny appraisal rights to the shareholders of companies the stock of which is publicly traded in an active market. E.g., Del. Code ANN. tit. 8, § 262(k) (Supp. 1978); N.J. STAT. ANN. § 14A: 11-1 (West Supp. 1978); see M. EIsENBERG, supra note 7, at 79-84 (criticizing such statutes as failing to recognize that market does not always reflect fair value and that stock price will be depressed immediately by news of ill-conceived structural change).

78. Most state statutes expressly grant corporations the right to purchase shares of another corporation. See, e.g., N.Y. Bus. CoRP. LAw $\$$ 202(a)(6) (McKinney 1963). Such a statutory grant may authorize an acquisition regardless of the exact provisions of a company's certificate of incorporation. See Danziger v. Kennecott Copper Corp., No. 21941/77, slip op. at 5-6 (Sup. Ct., N.Y. Cty. Dec. 5, 1977), aff'd mem., 60 A.D.2d 552, 400 N.Y.S.2d 724 (1977). 


\section{Diversifying Acquisitions}

fraudulent, in violation of a relevant statutory provision, or a breach of fiduciary duty. ${ }^{79}$ Since the decision to acquire another company for diversification purposes rarely involves active fraud or statutory violation, ${ }^{80}$ damaged shareholders must rely upon an allegation of a breach of the fiduciary duty of managers as a means of challenging an acquisition.

Officers and directors of a corporation are required to exercise their obligations in good faith and with the reasonable care of a prudent man. ${ }^{81}$ All actions must be in the interests of the corporation and not for personal benefit. ${ }^{82}$ The level of scrutiny imposed by this standard is severely restricted, however, by application of the business judgment rule: a court will not substitute its judgment for that of the managers when the wisdom, as opposed to the legality, of a decision is at issue. ${ }^{83}$ The business judgment rule is based upon the assumption that, in the absence of fraud or bad faith, shareholders are protected by economic forces. ${ }^{84}$

The only situation in which courts will regularly refuse to apply the business judgment rule is when a conflict of interest is evident. ${ }^{85}$ This occurs when the facts show a conflict between "forces tending towards a decision for the advantage of all the shareholders and those tending to the personal advantage of the directors." 86 Courts will investigate such transactions to ensure fairness unless there has been a ratification of

79. See Danziger v. Kennecott Copper Corp., No. 21941/77, slip op. at 3 (Sup. Ct., N.Y. Cty. Dec. 15, 1977) (if proposed acquisition is not ultra vires or statutory violation, then it will be deemed illegal only if shareholders can prove breach of fiduciary duty).

80. See Muschel v. Western Union Corp., 310 A.2d 904, 908 (Del. Ch. 1973) (in order to prove fraud, the discrepancy between price and value in proposed merger must be so gross as to lead court to conclude that it was not due to honest error in judgment, but rather to bad faith).

81. See, e.g., N.Y. Bus. CoRp. LAw $\$ 717$ (McKinney 1963); cf. CAL. CoRP. Code $\$ 310$ (West 1977) (procedures for validating transactions in which one or more directors had conflict of interest). See generally H. Ballantine, Ballantine on Corporations 158 (1946); H. Henn, Handiook of the Law of Corporations and Other Business Enterprises 453-59 (1970).

82. Vogel v. Lewis, 25 A.D.2d 212, 215, 268 N.Y.S.2d 237, 240-41 (1966), aff'd, 19 N.Y.2d 589, 224 N.E.2d 738, 278 N.Y.S.2d 236 (1967); Litwin v. Allen, 25 N.Y.S.2d 667, 678 (Sup. Ct. 1940).

83. In practice application of the doctrine is actually a determination either to review a business decision in full or to grant summary judgment. Note, The Continuing Viability of the Business Judgment Rule As a Guide for Judicial Restraint, 35 Geo. WASH. L. REv. 562, 564 (1967); see, e.g., Danziger v. Kennecott Copper Corp., No. 21941/77, slip op. at 5 (Sup. Ct., N.Y. Cty. Dec. 15, 1977) (granting summary judgment to purchasing corporation in suit alleging waste of corporate assets because shareholders did not establish material facts sufficient to justify trial on issue of breach of fiduciary duties).

84. Note, supra note 83 , at 569 .

85. Id. at 564; Bayer v. Beran, 49 N.Y.S.2d 2 (Sup. Ct. 1944) (when directors instituted advertising campaign featuring wife of one director, court refused to investigate decision to advertise but carefully scrutinized decision to hire wife because of possibility of conflict).

86. Note, supra note 83 , at 564 . 
management action by a majority of shareholders. ${ }^{87}$ Since courts will not examine a decision to diversify in the absence of proof of fraud or illegality, ${ }^{88}$ it is evident that they do not recognize that diversification opportunities may work to the managers' personal advantage without providing any corresponding advantage to the shareholders.

Most state statutes governing corporate mergers and consolidations provide for approval by and appraisal rights for shareholders of the surviving corporation, ${ }^{89}$ but the number of business combinations to which these statutes apply is limited. ${ }^{90}$ Recently, many states have further restricted approval rights for acquirer's shareholders to transactions in which the increase in shares resulting from an acquisition equals twenty percent or more of the acquirer's previously outstanding shares. ${ }^{91}$ Therefore, the acquirer often has the power to determine the approval rights of its shareholders by its choice of the format and method of payment for an acquisition. ${ }^{92}$

Under federal law, the Williams Act ${ }^{93}$ governs tender-offer purchases, which are outside the scope of state merger statutes. However, the Williams Act focuses on protection of the target's shareholders and offers little protection to the shareholders of the acquiring company. ${ }^{04}$

87. H. Ballantine, supra note 81, at 176; H. Henn, supra note 81, at 469; see Note, supra note 83 , at $\mathbf{5 7 1}$.

88. See, e.g., Danziger v. Kennecott Copper Corp., No. 21941/77, slip op. at 4 (Sup. Ct., N.Y. Cty. Dec. 15, 1977) ("It is not disputed that Kennecott's general goal of diversification is a proper one, calculated to improve Kennecott's earnings. . . . It has not even been suggested that Kennecott's officers and directors have approved the Carborundum purchase offer in furtherance of some improper or illegal plan, or out of sclf-interest.")

89. See, e.g., Dex. Code ANN. tit. 8, $\$ \$ 251,262$ (1978); N.Y. Bus. CoRP. LAw $\$ \$ 903$, 910 (McKinney Supp. 1978).

90. M. EisenberG, supra note 7, at 215 \& n.l. Most state statutes govern only the traditional formal merger or consolidation in which two companies join together to form a single legal entity. See, e.g., Del. Code ANN. tit. 8, $\$ 251$ (1978); N.Y. Bus. Corp. LAw $\$ \S 902,903$ (McKinney Supp. 1978).

91. E.g., Del. Code ANN. tit. 8, § 251(8) (1978) (if amount of stock issued in merger or consolidation exceeds $20 \%$ of shares outstanding immediately prior to effective date of merger, acquirer's shareholders have approval rights); N.J. STAT. ANN., \$ I4:10-3(4)(b) (West Supp. 1978) (approval rights for acquirer's shareholders if number of shares issued exceeds $20 \%$ of number of shares outstanding prior to merger). See generally B. WaSSERSTEIN, Corporate Finance Law 204-05 (1978).

92. See Farris v. Glen Alden Corp., 393 Pa. 427, 432, 143 A.2d 25, 28 (1958) (court found transaction structured as sale of assets to be "de facto" merger; new accounting and legal forms of corporate combination had been developed in order "to avoid the impact of adverse, and to obtain the benefits of favorable, government regulations"). The de facto merger doctrine derived from Farris has been used by courts to thwart such attempts to circumvent the requirements of merger statutes. See, e.g., Applestein v. United Bd. \& Carton Corp., 60 N.J. Super. 333, 159 A.2d 146 (Super. Ct. Ch. Div. 1960), aff'd per curiam, 33 N.J. 72, 161 A.2d 474 (1961).

93. I5 U.S.C. $\$ \$ 78 l(\mathrm{i}), 78 \mathrm{~m}(\mathrm{~d})$-(e), $78 \mathrm{n}(\mathrm{d})-(\mathrm{f})(1976)$.

94. See Piper v. Chris-Craft Indus., Inc., 430 U.S. 1, 35, 42 (1977) (purpose of Williams Act to protect shareholders of target companies and therefore no implied right of action exists for parties outside protected class). See also Santa Fe Indus., Inc. v. Green, 430 U.S. 462, 479-80 (1977) (Rule 10b-5 does not create uniform federal law of fiduciary duty). 


\section{Diversifying Acquisitions}

In sum, the damaged shareholder must demonstrate his disapproval of a diversifying acquisition by selling his shares. $\mathrm{He}$ is, therefore, forced to take a loss in order to protect himself against management actions that do not maximize shareholder wealth. The law should be reformed to recognize this latent conflict between managerial motivations and the best interests of the shareholders.

\section{B. A Proposal for Reform}

There are three possible means of creating legal remedies for damaged shareholders of an acquiring company: (1) state statutes requiring approval, with accompanying disclosure and appraisal rights, by the acquirer's shareholders; (2) federal legislation creating a cause of action on behalf of the acquirer's shareholders or articulating federal fiduciary standards; and (3) removal of the application of the business judgment rule to acquisition decisions.

First, state-law approval rights could be granted to shareholders of all companies involved in a business combination; such rights would allow shareholders to protect themselves by refusing to ratify a nonsynergistic merger. There are, however, several drawbacks to such statutory reforms. Since shareholders routinely ratify management actions, ${ }^{05}$ approval rights afford little actual protection. Appraisal rights are similarly ineffectual; 90 the delay and expense for the acquirer involved in approval and appraisal procedures would burden valid transactions. ${ }^{97}$ Furthermore, given the difficulty of distinguishing beneficial from nonbeneficial transactions without judicial factfinding, there is no assurance that such procedures would produce economically desirable results. Finally, disclosure of a potential acquirer's plans for a target company to shareholders, pursuant to an approval procedure, would give competing acquirers an undeserved advantage; farsighted acquirers should retain the benefits of their synergistic acquisitions.

Second, even if the federal securities laws were extended to protect the shareholders of acquirers, disclosure alone, without rights of approval, would only afford shareholders protection against procedural irregularities. ${ }^{98}$ Management decisions will still be immune from substantive shareholder attack. Although substantive reform and expansion of federal law is theoretically possible, the Supreme Court has indicated an unwillingness to do so through judicial decision. ${ }^{99}$

95. Chirelstein, Corporate Law Reform, in Social Responsibility and THE Business Predicament 46.47 (J. McKie ed. 1974).

96. See M. EISENBERG, supra note 7, at 83 (characterizing appraisal rights as "remedy of desperation").

97. See E. Kintner, supra note 40, at 29.30; B. WAsserstein, supra note 91, at 205-06.

98. See M. EISENBERG, supra note 7, at 35.

99. See, e.g., Santa Fe Indus., Inc. v. Green, 430 U.S. 462 (1977). 
Substantive common law reform is most likely to provide adequate shareholder protection. Such reform is consistent with the theoretical basis of the business judgment rule, since the rule is not applied to decisions made in conflict of interest situations. Because forces tending to the personal advantage of management exist in acquisition decisions, such decisions, although not void per se, should be voidable by a court upon proof of unfairness. ${ }^{100}$ In establishing the fairness of an acquisition, management should have the burden of proving that the premium paid for the acquired company is justified by the existence of some measurable benefit for shareholders. ${ }^{101}$

It is difficult to project accurately the benefits arising from an acquisition. ${ }^{102}$ However, in assessing the fairness of a transaction, it would generally be possible for a court to determine whether the shareholders of the acquiring company receive benefits in excess of the price paid. There are certain "benefits" that are spurious and should be rejected by a court. For example, "boot-strapping," manufacturing growth by continuous acquisition of companies with lower price-earnings ratios than the acquirer, ${ }^{103}$ does not provide the shareholder with real added value. ${ }^{104}$ Diversification, or the reduction of risk in order to stabilize earnings, similarly cannot justify an acquisition. ${ }^{105}$ Other benefits may potentially create value for the acquirer's shareholders but are unlikely to be realized in most situations. These generally unrealized benefits include transfer of competent management to a currently mismanaged target company, ${ }^{106}$ the investment of excess funds, ${ }^{107}$ and a reduced cost of capital due solely to the combination. ${ }^{108}$

100. See Note, supra note 83 , at 567-68.

101. See, e.g., Alcott v. Hyman, 208 A.2d 501 (Del. Ch. 1965).

102. See generally Alberts, supra note 53. One commentator has noted that the atmosphere of the market affects the investor's predictions about an acquisition: "In a bull market, acquisitions are generally considered synergistic, and almost anything goes. In a bear market the Street is antagonistic and just about nothing goes. In a chicken market, the street is neurotic and it is anyone's guess what goes." Balog, Why the Stock Market Reacts the Way It Does to Announcements of Mergers and Acquisitions, Financial ANaLYsTs J., Mar.-Apr. 1975, at 84, 87-88.

103. See note 52 supra.

104. See Myers, supra note 52, at 638-40.

105. Id. at $637-38$.

106. See U. ReINHARDT, supra note 56 , at 4 (difficulty of managing widely diversified and geographically dispersed conglomerate may well be such as to lead, on balance, to negative synergism); Mueller, supra note 41 , at $651-53$ (managerial economies exist only if managerial ability can be applied with equal success to unrelated businesses and if managers of acquiring firm have greater abilities than managers of corporation they acquired); cf. Wall St. J., Sept. 6, 1978, at 1, col. 6 (most recent acquisitions have been of already well-managed firms, thus reducing possibility of managerial synergy).

107. See R. BREALEY, supra note 63, at 51 (price of company's stock better protected by increase in dividends or repurchase of its own shares).

108. See U. ReInhardt, supra note 56, at 47 (in absence of other synergistic benefits, reduced cost of capital is possible only to extent that there are imperfections in capital markets; effect of those imperfections on cost of capital is extremely difficult to measure). 
On the other hand, the likelihood that production-oriented operating economies and financial economies will result from an acquisition is relatively easy to ascertain. For example, when companies are in related businesses with compatible product lines, benefits from this compatibility should be evident in a thorough study of each company's business. ${ }^{109}$ Financial economies such as the use of previously unusable tax-loss carryforwards or unutilized debt capacity ${ }^{110}$ are readily ascertainable by a financial analyst. Courts should evaluate claims of these benefits in light of the facts of the particular case in order to determine the likelihood that these benefits will materialize. If a court is satisfied that benefits to shareholders from the acquisition exceed the total costs, it may reasonably assume that the acquisition comports with fiduciary standards. ${ }^{111}$

The longrun effect of this common law reform would be to make mergers very difficult to achieve. The antitrust laws substantially impede all horizontal and vertical mergers, ${ }^{112}$ which are the combinations most likely to produce synergistic benefits. The reform suggested here would prohibit all mergers that provide no benefit other than diversification. Thus, the only acquisitions that would be permitted would be synergistic combinations of unrelated businesses. Such a result would clearly be more beneficial to the economy as a whole than an absolute prohibition of acquisitions by companies above a given size; ${ }^{113}$ common law reform is best able to create the kind of protection that is needed for acquirers' shareholders without impeding or prohibiting those transactions that do maximize shareholder wealth.

109. For a discussion of potential merger benefits, see Myers, supra note 52, at 635-37.

110. The existence of these redundant assets is likely to be recognized by other potential acquirers. Therefore, the price of the target may be quickly bid up beyond the value of acquiring those assets. See id. at 636 .

111. In fixing management compensation, boards of directors should bear these same factors in mind. Bonuses should reward true operating performance gains, not growth for growth's sake. Since diversification without synergy actually harms shareholders, providing reward for the execution of such transactions could, in fact, constitute a breach of the board members' fiduciary duties.

112. See L. Suldivan, Handbook of the LAw of Antitrust 600-02, 657-61 (1977).

113. See Wall St. J., Dec. 29, 1978, at 4, col. 2 (discussing proposals for prohibiting mergers above given size). 